\title{
ANALISA PENGARUH KUALITAS PELAYANAN TERHADAP KEPUASAN PELANGGAN KARTU PRABAYAR DAN PASCA BAYAR PADA GRAPARI TELKOMSEL
}

\author{
Adi Hermawansyah, Siti Hamidah, Jatiah \\ STMIK BORNEO INTERNASIONAL BALIKPAPAN \\ adi.hermawansyah26@gmail.com, midahchandra46@gmail.com, \\ tyamaniez2006@yahoo.com
}

\begin{abstract}
ABSTRAK
PT. Telkomsel adalah perusahaan operator seluler pertama di Indonesia yang mendukung perkembangan jaringan telepon seluler dan memiliki kios GraPARI di seluruh Indonesia, sehingga pelayanan pelanggan harus memberikan layanan yang baik kepada pelanggan, karena dengan kualitas layanan yang baik akan mempengaruhi tingkat kepuasan pelanggan. Penulis melakukan penelitian ini bertujuan untuk menganalisis pengaruh kualitas pelayanan terhadap kepuasan pelanggan kartu prabayar dan pascabayar pada GraPARI Telkomsel Penajam, hasil yang dicapai mengarah pada responden pelanggan terhadap kualitas pelayanan pelanggan GraPARI Telkomsel Penajam. Strategi promosi merupakan suatu strategi yang terencana yang kompherensif dan terpadu yang diperlukan untuk mencapai tujuan perusahaan dan sasaran promosinya. Berdasarkan pengecekan dari Aplikasi SQMO dari 550 sms survey yang dikirim kepada pelanggan telkomsel yang merespon puas sebanyak 318 pelanggan dan yang merespon tidak puas sebanyak 1 pelanggan. Hal ini menunjukkan jika strategi promosi pada GraPARI Telkomsel Penajam sudah tertata dengan baik. Dari hasil analisa yang dilakukan pada GraPARI Telkomsel penajam maka dapat seyogyanya agar lebih lagi dalam hal meningkatkan metode dan strateginya dalam promo baru Telkomsel dan selalu memberitahukan kepada seluruh masyarakat terkait produk-produk terbarukan.
\end{abstract}

Kata kunci: GraPARI, kepuasan pelanggan, kualitas layanan,

\section{PENDAHULUAN}

Era telepon selular, khususnya Global System for Mobile communications (GSM), memang baru marak dalam beberapa tahun belakangan ini. Dari segi teknologi dan merek serta jenis, ponsel yang beredar di Indonesia sama sekali tidak ketinggalan dari negara lain. Performance sebuah ponsel sangat tergantung pada kecepatan mengatasi masalah after sales service yang sangat diharapkan oleh pelanggan. 
Telkomsel secara konsisten telah mengimplementasikan teknologi seluler terkini dan menjadi yang pertama meluncurkan secara komersial layanan mobile 4G LTE di Indonesia. Memasuki era digital, Telkomsel terus mengembangkan bisnis digital, diantaranya Digital Advertising, Digital Lifestyle, Mobile Financial Services, dan Internet of Things. Untuk melayani kebutuhan pelanggan, Telkomsel menggelar call center 24 jam dan layanan GraPARI dan memiliki 411 kios GraPARI yang tersebar di seluruh Indonesia, salah satunya GraPARI di Kabupaten Penajam Paser Utara yang memiliki jumlah kunjungan pelanggan yang cukup tertinggi

Kualitas Pelayanan, Fungsi dan manfaat dari suatu produk merupakan fokus perhatian konsumen. Kebutuhan konsumen yang terus meningkat dan didasari oleh tingkat kekritisan yang semakin tinggi, cenderung menuntut pelayanan secara pribadi dan ikut dilibatkan dalam pengembangan suatu produk. Hal inilah yang menjadi dasar pemikiran untuk tetap memenuhi kebutuhan, keinginan dan harapan konsumen dalam segala perubahan sehingga tidak akan berpaling ke produk substitusi

Tujuan dari penelitian ini adalah untuk mengetahui apakah kualitas kinerja karyawan dalam melayani konsumen sudah sangat baik atau masih ada keluhan dari konsumen, penelitian ini dikhususkan pada kualitas kinerja pelayanan yang diberikan oleh GraPARI Telkomsel Penajam Paser Utara pada pelanggan.

\section{KERANGKA TEORI}

Dalam proses penelitian, peneliti mencari teori-teori, konsep-konsep dan generalisasigeneralisasi hasil penelitian yang dapat dijadikan sebagai landasan teoritis untuk pelaksanaan penelitian. Teori merupakan alur logika atau penalaran yang merupakan seperangkat konsep, definisi, proposisi yang disusun secara sistematis. Secara umum teori mempunyai tiga fungsi, yaitu untuk menjelaskan, meramalkan dan pengendalian

Pada prinsipnya analisis pengaruh kualitas pelayanan terhadap kepuasan pelanggan penggunaan kartu prabayar \& pasca bayar pada grapari telkomsel merupakan wujud dari peningkatan pelayanan karena berawal dari analis itulah dapat dijadikan dasar untuk pelayanan lebih baik ke depannya.

Teori pelayanan antara lain : 
1. Layanan adalah suatu perbuatan.

2. Layanan adalah sebuah produk yang memberikan solusi kepada pelanggan.

3. Layanan adalah suatu sikap yang dapat mengakibatkan rasa puas atau tidak puas yang dialami pelanggan.

4. Layanan adalah kunci kesuksesan sebuah bisnis.

5. Layanan adalah proses untuk mengubah produk yang biasa-biasa saja menjadi produk yang sangat luar biasa.

6. Layanan adalah upaya untuk memenuhi harapan pelanggan.

7. Layanan adalah strategi untuk keluar dari kerumunan.

8. Layanan merupakan kegiatan yang dapat dijual kepada orang lain

Kepuasan pelanggan berjalan berbarengan dengan ketidakpuasan. Artinya respons pelanggan terhadap evaluasi dan ketidaksesuaian yang dirasakan antara harapan sebelumnya dan kinerja aktual produk yang dirasakan setelah pemakaiannya . Jadi kepuasan adalah suatu tanggapan emosional yang dirasakan oleh pelanggan pada saat mereka menikmati pengalaman menggunakan atau mengkonsumsi produk / jasa. Dengan demikian kepuasan pelanggan adalah evaluasi pasca pembelian, dimana alternatif yang dibeli minimal sama atau melebihi harapan pelanggan. Berdasarkan pengertian ini maka kepuasan pelanggan adalah tingkat perasaan seseorang setelah membandingkan kinerja atau hasil yang ia rasakan dibandingkan dengan harapannya

Menurut [3] menjelaskan bahwa customer service ialah memberikan apa yang diinginkan pelanggan secara konsisten dan continue, maka pelanggan akan selalu terkenang [3]. Sehingga intinya customer service melayani segala keperluan nasabah secara memuaskan Tugas dan fungsi customer service adalah seorang customer service harus pandai dalam mencari jalan keluar untuk menyelesaikan berbagai masalah - masalah yang dihadapi pelanggan atau tamunya. Tugas customer service yaitu memberikan pelayanan yang prima dan membina hubungan baik dengan nasabah, klien atau pelanggan. Seorang customer service juga harus bertanggung jawab dari awal sampai akhir dari pelayanan tersebut. Customer service juga berfungsi sebagaimana di bawah ini:

1. Penerima Tamu; dalam hal ini seorang customer service melayani pertanyaan pertanyaan yang diajukan tamu serta memberikan informasi yang diinginkan selengkap mungkin secara ramah, sopan, menarik dan menyenangkan. Harus selalu memberikan 
perhatian, bicara dengan suara jelas dan serta lembut, dan memakai bahasa yang mudah dimengerti klien.

2. Customer Relation Office; artinya bahwa customer service yaitu orang yang dapat membina hubungan baik dengan klien/pelanggan. Sehingga merasa puas, senang dan juga semakin percaya.

3. Komunikator; dengan cara memberikan berbagai informasi dan kemudahan- kemudahan kepada tamunya, juga sebagai tempat menampung berbagai macam keluhan, keberatan ataupun sebagai tempat konsultasi.

Berdasarkan uraian di atas, maka dapat dihubungkan bahwa customer service adalah setiap kegiatan yang ditujukan untuk memberikan kepuasan melalui pelayanan yang diberikan seseorang kepada kliennya dalam menyelesaikan masalah dengan memuaskan. Pelayanan yang diberikan termasuk menerima keluhan atau masalah yang sedang dihadapi.

\section{METODE PENELITIAN}

\section{Metode Penelitian}

Metode diperlukan agar tujuan penelitian dapat tercapai sesuai dengan rencana yang telah ditetapkan. Metode penelitian diartikan sebagai cara ilmiah untuk mendapatkan data dengan tujuan dan kegunaan tertentu

Dalam penelitian ini penulis menggunakan metode penelitian kualitatif yang bersifat deskriptif dan cenderung mengunakan analisis. Dan teknik pengumpulan data yang digunakan adalah menggunakan teknik observasi dan studi pustaka.

1. Teknik Observasi

Teknik observasi merupakan salah satu teknik metode studi lapangan dengan cara mengamati atau menganalisis secara langsung keadaan dilapangan tempat penelitian yang dituju kantor Grapari Telkomsel Penajam. Dengan teknik ini peneliti dapat menilai atau menganalisis secara real data yang diperoleh dari hasil teknik metode studi lapangan lainnya. Observasi merupakan teknik pengumpulan data dengan melihat kegiatan langsung dilapangan 


\section{Studi Pustaka}

Pengumpulan data sekunder dilakukan dengan studi pustaka sebagai bahan referensi, serta untuk mendukung informasi dalam penelitian yaitu dengan menggunakan sumber teori dan buku. Metode ini dilakukan dengan cara mengumpulkan, membaca, dan mempelajari data-data yang ada di berbagai media, seperti buku,karya tulis, jurnal atau artikel dari internet

\section{HASIL DAN PEMBAHASAN}

\section{Hasil}

Untuk melakukan tahapan awal sebelum pengecekan di aplikasi SQMO ini harus memasukkan nomer kartu pelanggan ke sebuah aplikasi CRM (Customer Relationship Management) yang berfungsi sebagai strategi untuk mengelola atau memanage hubungan dengan konsumen sampai menjadi pelanggan tetap, dengan menggunakan aplikasi CRM maka dengan mudah akan membantu kita mengelola data konsumen kita. Manfaat aplikasi CRM antara lain :

1. Memudahkan customer

2. Fitur pengelompokan jadwal yang ada pada aplikasi CRM akan sangat memudahkan kita mengelola data customer kita. kita tidak perlu lagi membuka email, chat, sms, telpon dan histori panggilan telpon.

3. Aplikasi CRM juga sangat membantu kita dalam hal follow up customer menjadwal dan mengirimkan notifikasi.

4. Mengetahui posisi (Customer) .

5. Mempermudah memberikan "after sales" yang berkualitas.

Untuk mengetahui hasil kepuasan atau tidak puasnya pelanggan pengguna kartu prabayar dan pascabayar, GraPARI Telkomsel Penajam akan mengirimkan sms survey 1166 kepada konsumen yang telah mengunjungi kios GraPARI melalui aplikasi CRM dan untuk mengetahui hasil berapakah konsumen yang merespon sms survey ialah dengan melalui aplikasi SQMO, dimana aplikasi SQMO yang ada pada GraPARI Telkomsel dapat mengetahui berapakah pelanggan yang merespon sms survey dan berapakah yang tidak merespon sms survey tersebut serta dapat mengetahui berapakah pelanggan yang memberi 
tanggapan puas dan tidak puas. GraPARI Telkomsel Penajam melakukan pengecekan sms survey dengan cara akumulasi seperti pada gambar berikut :

Gambar 1.

Hasil Sms Survey pada Aplikasi SQMO

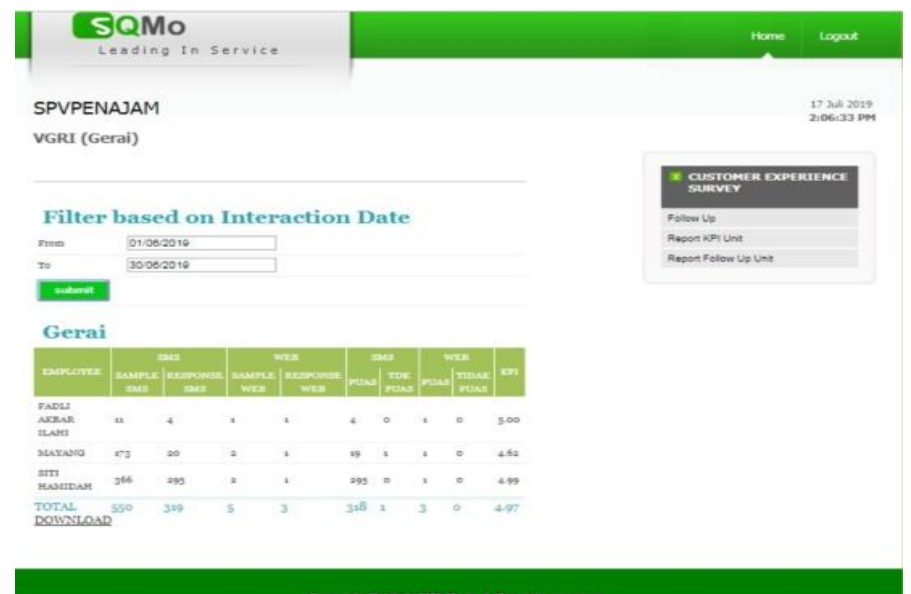

\section{Pembahasan}

Pada gambar di atas memperlihatkan hasil keseluruhan dari sms survey di bulan juni 2019, dari tanggal 1 s/d 30 juni 2019 sebanyak 550 sms Survey dikirim kepada pelanggan telkomsel akan tetapi hanya 319 pelanggan yang merespon sms survey tersebut, yang merespon puas sebanyak 318 pelanggan dan yang merespon tidak puas sebanyak 1 pelanggan.

Gambar 2.

Struktur Organisasi

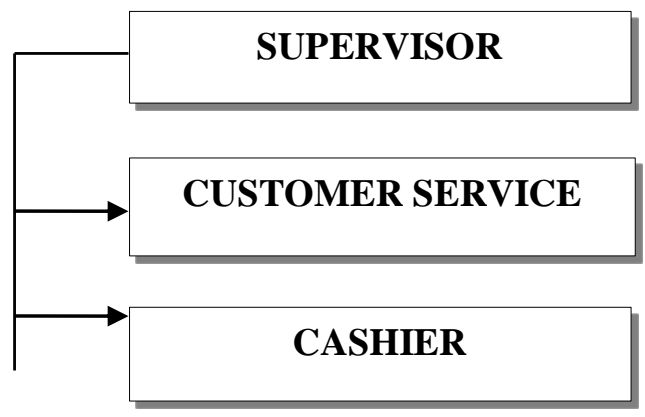

Uraian Tugas pada struktur organisasi di GraPARI Telkomsel Penajam merupakan wujud dari salah satu peningkatan pelayanan. Ada pun uraian tugas sebagai berikut :

1. Supervisior 
Mengatur pekerjaan para staf yang ada dibawahnya meliputi membuatkan job desc, memotivasi, membuat jadwal kegiatan, melaksanakan briefing serta menentukan pekerjaan apa saja yang akan dilakukan dalam jangka waktu pendek maupun jangka panjang.

\section{Customer Service}

Customer service bertujuan untuk setiap kegiatan yang ditujukan untuk memberikan kepuasan melalui pelayanan yang diberikan seseorang kepada kliennya dalam menyelesaikan masalah dengan memuaskan. Pelayanan yang diberikan termasuk menerima keluhan atau masalah yang sedang dihadapi.

\section{Cashier}

Uraian tugas dari cashier adalah menjalankan proses penjualan dan pembayaran serta hal lain yang relevan yaitu melakukan pencatatan atas semua transaksi, membantu pelanggan dalam memberikan informasi mengenai suatu produk, melakukan proses transaksi pelayanan jual beli.

\section{PENUTUP}

\section{Kesimpulan}

Berdasarkan hasil penelitian dan pembahasan diatas, maka dapat diambil kesimpulan bahwa kinerja karyawan khususnya pada kualitas pelayanan terhadap pelanggan kartu prabayar dan pascabayar pada GraPARI Telkomsel Penajam sangat mempengaruhi tingkat kepuasan pelanggan.

\section{Saran}

Berdasarkan kesimpulan diatas, selanjutnya dapat diusulkan saran yang diharapkan dapat bermanfaat bagi GraPARI Telkomsel Penajam yaitu untuk mencegah terjadinya keluhan pelanggan serta kesalahan dalam melayani pelanggan kartu prabayar dan pascabayar GraPARI Telkomsel hendaknya melakukan pelatihan serta bimbingan teknis terhadap karyawannya, serta meningkatkan kualitas kinerja, khususnya pada pelayanan agar dapat memenuhi harapan konsumen.

\section{Ucapan Terimakasih}

Alhamdulillah puji syukur kepada Allah swt, karena kehendak dan ridha - Nya penulis dapat menyelesaikan artikel ini. Penulis sadari paper ini tidak akan selesai tanpa do'a, 
dukungan dan dorongan dari berbagai pihak serta tidak lupa penulis ucapkan terima kasih kepada seluruh pihak yang telah membantu dalam memberikan informasi berkaitan dengan penulisan artikel ini.

\section{DAFTAR PUSTAKA}

https://www.telkomsel.com

Sugiyono (2015), Metode Penelitian dan Pengembangan untuk Bidang Pendidikan, Manajemen, Sosial dan Teknik. Bandung: Penerbit Alfabeta

Rangkuti, Freddy (2013), Customer service satifaction \& call center berdasarkan iso 9001.

Sugiyono (2015), Metode Penelitian dan Pengembangan untuk Bidang Pendidikan, Manajemen, Sosial dan Teknik. Bandung: Penerbit Alfabeta

Sutarbi, Tata (2012), Analisis sistem informasi. Yogyakarta : Penerbit Andi Offset Indrajani, S, Kom, MM (2017), Database Design (Theory, Practic, and Case Study). $\quad$ Jakartra: Penerbit PT Elex Media Komputindo. 